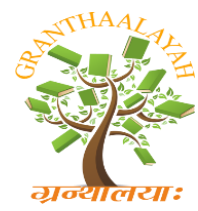

Arts

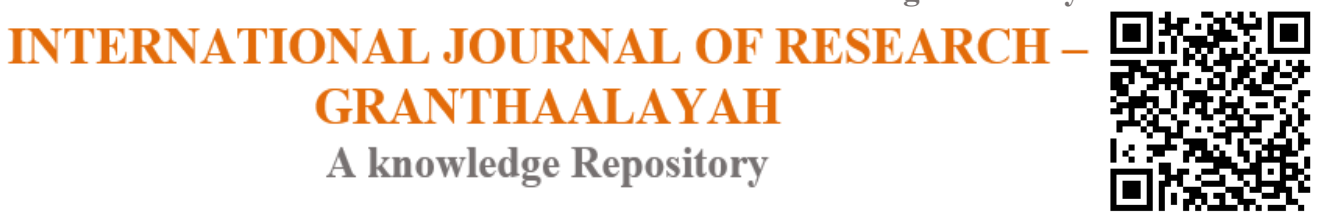

\title{
WOOD CRAFT OF BIHAR AND UTTAR PRADESH -A SURVEY
}

\author{
Dr. Anjali Pandey *1 \\ ${ }^{* 1}$ Assistant Professor (Drawing \& Painting), Govt. M.L.B. Girls P.G. College Bhopal, INDIA
}

\begin{abstract}
The tradition of wood carving is old. Wood craft is quite popular in Bihar and Uttar Pradesh. Craftsmen of these states are using their skill for making the designs in traditional and innovative way. A unique engraving creativity of 'Nakkashi work' appears with floral and figures etched out by the craftsmen. Lacquer work is obviously one of the major handicrafts of these regions. Various motifs of birds, peacock, fish, carved on the wood, appeals the viewers. The items made out of bamboo and wood are crafted in the shapes of birds, human figures and animals. Figures of Gods and Goddesses, animals and many mythological figures are crafted by the local craftsmen. The dolls, peacocks, parrots, elephants, horses, goats, bulls and cows are the repertoire of rural children. Uttar Pradesh is world known for its carved and brass inlayed or tarkashi wooden handicrafts. The craftsmen of Saharanpur are excelled in the art of inlayed wood work it is now widely used to decorate the centre-table, ash-trays, fruitbasket, service tray and other furniture articles etc. Varanasi and Amroha are particularly well known for lacquered woodcraft of UP. Numbers of lacquered toys, miniature kitchen utensils for children are made in this state.
\end{abstract}

Keywords:

wood carving, craftsmen, Nakkashi work, Motifs, Brass inlay, lacquered woodcraft.

Cite This Article: Dr. Anjali Pandey, "WOOD CRAFT OF BIHAR AND UTTAR PRADESH A SURVEY” International Journal of Research - Granthaalayah, Vol. 4, No. 2 (2016): 239-242.

\section{INTRODUCTION}

"As man came to acquire greater control over his environment, he wandered into newer sectors, trying, testing, and perfecting other raw materials to meet his growing needs, adding more variety, savoring fresh experiences. Wood was the most natural and something alluring about the grain of the wood, with multi-tinted shades flowing, and a texture with a glow on it".

Wood is mainly used for craft work in India as it is commonly available. The pillars, ceremonial arch, raths and carriages, beams of roofs, religious images, ornaments and other artistic or utilitarian articles represents the wood culture of India. ${ }^{2}$ Almost in every Indian village the artisans are engaged in the production of wood turnery items. ${ }^{3}$ 
The Traditional wooden handicrafts of Bihar and Utter Pradesh express the great tradition of their states. The Woodcraft made in U. P. and Bihar is made in the most ethnic and the traditional way. Craftsmen of these states are using their skill for making the designs in traditional and innovative way. Figures of Gods and Goddesses, animals and many mythological figures are crafted by the local craftsmen, furniture and other useful items are also made in these region. ${ }^{4}$

\section{BIHAR}

Man has developed deep sense of aesthetics which he derived from well done job of creation. Utility is essential part in completeness of life and ornamentation creates the aesthetic value.

A unique engraving creativity of 'Nakkashi work' appears with floral and animal figures etched out by the craftsmen. The sharpness of line, the varied forms of designs speaks intricacy of craftsmanship. Various

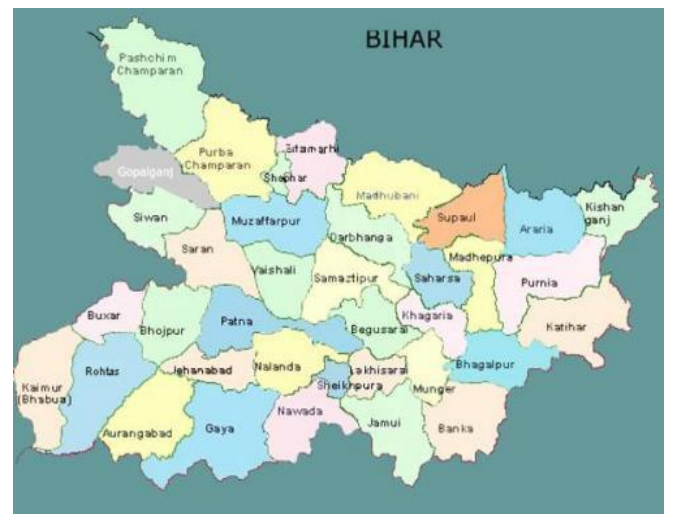
motifs of birds, peacock, fish, carved on the wood, appeals the viewers. Every items turned out is the creative expression of craftsmen ${ }^{5}$

Lacquer craft is obviously one of the major handicrafts of this region. The varied forms of designs are the fine specimens of craftsmanship. A marked difference in style and design are the evidence of aristocratic and rural interest. Bihar produced the $40 \%$ contribution of India in lacquered craft production. It is called the 'Home of the Laac'. The important centers of woodcraft in Bihar are Patna, Ranchi, Darbhanga, Gaya etc. Many interesting and unique items are manufactured in attractive color scheme and are practiced in different style and design. Lac based yellow red and black color reveals in these articles. A esthetics sense of color reflects in these articraft. ${ }^{6}$

The articles of cane and bamboo reveal their skilled hands. The items made out of bamboo and wood are crafted in the shapes of birds, human figures and animals. Figures of Gods and Goddesses, animals and many mythological figures are crafted by the local craftsmen of Patna, Ranchi and districts. Varied furniture items, bed post legs, (machia legs) table lamps, sindoor dani, bowls, boxes and ash tray are some of articles produced out of wood. ${ }^{7}$

Wood and clay are common available material used for making toys ${ }^{8}$, Toys in Bihar are made in the most ethnic and the traditional way. Various designs of toys are also made in this region. The dolls, peacocks, parrots, elephants, horses, goats, bulls and cows are the repertoire of rural children. There is a tradition of making dolls by the women folk of almost every family and this craft is passed from mother to her daughter and this is how this craft is preserved in Bihar. Craftsmen also make dolls for the theatre craft .Bride and groom dolls are made and attract lot of attention. These are made from the bamboo, mud, cloth and wood. Craftsmen also design all the possible jewellery along with attractive colour. 


\section{UTTAR PRADESH}

Uttar Pradesh is world known for its carved and brass inlayed or tarkashi wooden handicrafts. Handicrafts made of ebony, haldoo, and mangos are well known for its durability, elegance and style. ${ }^{9}$ The craftsmen of Saharanpur are excelled in the art of inlayed wood work introduced by the Kashmiri artisan. Inlay is an ornamentation done by embedding pieces of different material in a surface. The materials generally used are metal, ivory bone or various types of wood like sandal

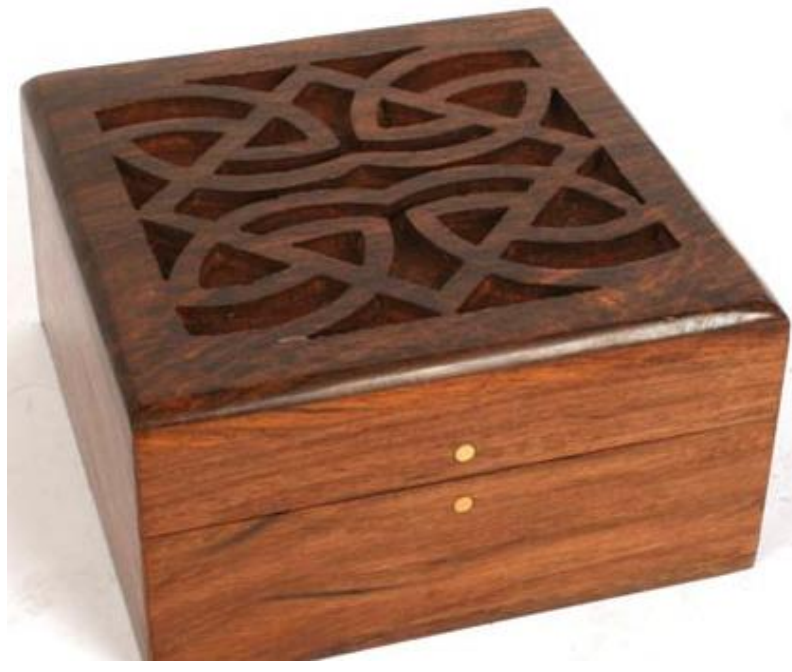

are inlayed with the help of tools for the ornamentation. Saharanpur is famous for its vineleaf pattern carving on hard sheeesham. Mainpuri of Uttar Pradesh is the prime centre of this art. ${ }^{12}$ The places in Uttar Pradesh which manufacture wooden handicrafts are, Almora, Nagina, Bijnaur, Bulandshahar, Khurja, Mainpuri, Mirzapur, Muradabad, and Uttrakashi.

Varanasi and Amroha are particularly well known for lacquered woodcraft of UP. Numbers of lacquered toys, miniature kitchen utensils for children are made in Varanasi. Chakla -belan, Sindoor-dani, and some other useful and ritual items are also covered the handicraft range. Ornamental lacquering with intricate patterns viz dana work, atishi, abri, zig-zag and Nakkashi. ${ }^{13}$

"The growth of crafts in society was the sign of the cultivation of sensivity and the stirring and mellowing of humanism"14. The Tradional wooden

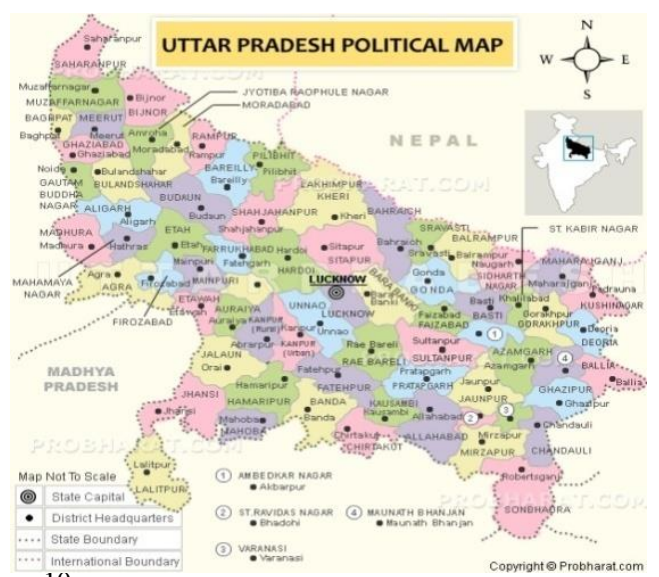

rose etc. ${ }^{10}$ Now these days when ivory is banned, artisans used the plastic for Inlay craft work. ${ }^{11}$ Furniture, Frames and toys with ornamental intricate pattern and traditional designs of jali, angoori, and takai including, floral figurative designs are available here. Wooden articles like bowls, trays and various decorative items are inlayed with brass or silver wire known as Tarkashi. This technique was originally done on wooden foot wears 'Kadaun' but it is now widely used to decorate the centre-table, ash-trays, fruit-basket, service tray and other furniture articles etc. The minute coils of metal wire

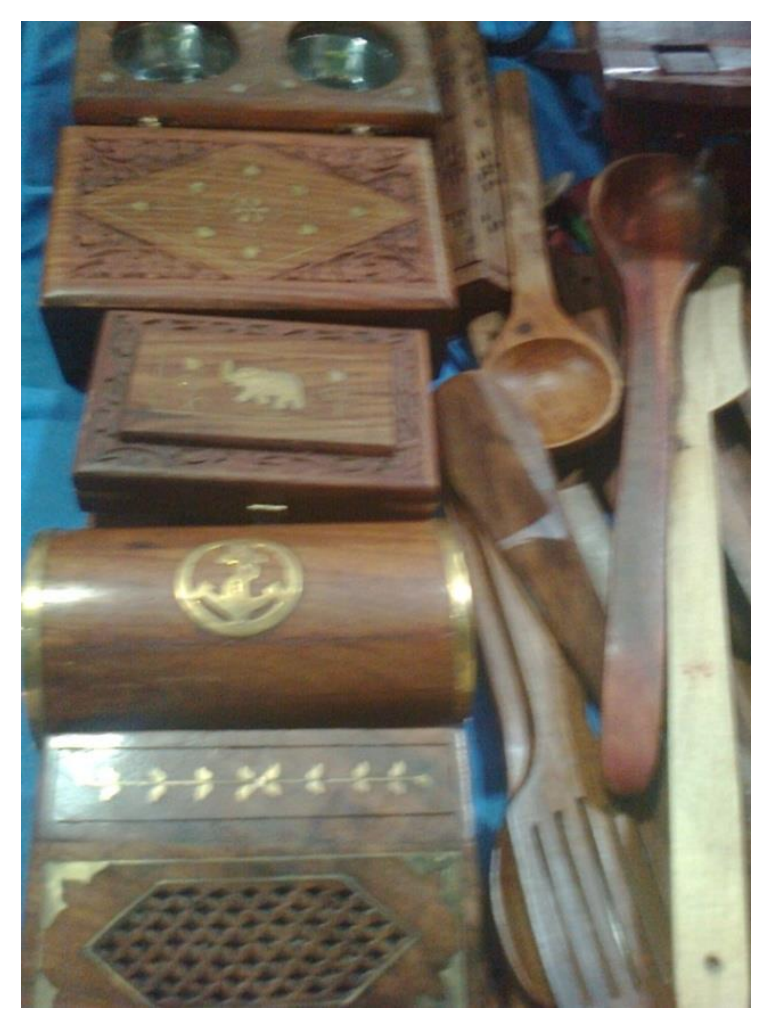


handicrafts of Bihar and Uttar Pradesh survived and developed because they were regarded as material symbols of unique cultural ethos of these state.It is obvious that beauty and utility of remote days can never divorsed in present days.

All India handicrafts board and Smallscale Industries Corporation has taken the initiative for the seccurity of work. They provide all possible help and assistance to the craftsmen. The Government also supersied the work of artists and gives award for their talents. Mohd. Shanawaz of Saharanpur and Sirajul Haq Of Banaras are leading artisans who practice the craft of Brass Inlay $^{15}$.

"I believe that our vitality as a people is intimately connected with the expression of the sense of beauty. A sense of beauty is nothing but a sense of quality, and if as a people we have lost the sense of quality we are finished"16

\section{REFERENCES}

[1] Chattopaddhyay KamalaDevi; India's Caft Tradition;Pub Div; New Delhi; 1980;2000

[2] Pathak Vikas: Wood craft in India www.importantindia.com

[3] Pal H. Bhisham: Handicrafts of Rajasthan Pg- 39

[4] Pandey Anjali: Wood Craft Of Madhya Pradesh "with special reference to art of carving on wood in Different Regions Of Madhya Pradesh M.R.P.

[5] Ibid

[6] Ibid

[7] googleweblight.com

[8] Ibid

[9] Marg-A magazine of the Arts Ed Anand Mulk Raj June 1966 Bombay;

[10] www.indianartisansonline.co

[11] Pandey Anjali: Ibid

[12] (www.indialine.com

[13] www.indialine.com

[14] Chattopaddhyay KamalaDev: Ibid

[15] www.indianartisansonline.co

[16] Vidyarthi L.P.: Art And Culture of North-East IndiaCh-6 Art And Crafts Pub Div New Delhi1993/'India's North East Frontier in the 19thCentury", Oxford University Press,Indian Branch, Calcutta, 1959.

[17] wwmapsofindia.com 